\section{Container Height and Douglas Fir Bark Texture Affect Substrate Physical Properties}

\author{
James S. Owen, Jr. ${ }^{1}$ \\ Oregon State University, North Willamette Research and Extension Center, \\ 15210 NE Miley Road, Aurora, OR 97002-9543
}

\author{
James E. Altland \\ USDA-ARS, Application Technology Research Unit, 208 Ag. Engineering \\ Building, 1680 Madison Avenue, Wooster, OH 44691
}

Additional index words. media, container capacity, air space, total porosity, water-holding capacity, moisture gradient, water management

\begin{abstract}
A study was conducted to quantify the effect of substrate texture on waterholding capacity of douglas fir [Pseudotsuga menziesii (Mirb.) Franco] bark (DFB) in containers of varying height. Medium (less than $2.2 \mathrm{~cm}$ ) and fine (less than $0.9 \mathrm{~cm}$ ) DFB were packed into $7.6 \mathrm{~cm}$ i.d. aluminum cores $3.8,7.6$, and $15.2 \mathrm{~cm}$ tall to determine container capacity (CC) and air space (AS) at varying container heights. Increasing container height resulted in a linear decrease in $\mathrm{CC}$ and a linear increase in AS. Fine texture DFB bulk density $\left(D_{b}\right)$ increased $18 \%$ with increasing container height, whereas $D_{b}$ of medium texture DFB was unaffected. Water-holding capacity decreased $20 \%$ and $42 \%$ in medium and fine textured DFB, respectively, with increasing container height from 3.8 to $15.2 \mathrm{~cm}$. A second study was conducted to investigate water distribution in a $15.2-\mathrm{cm}$ tall container for a given substrate texture. Polyvinyl chloride cores $(15.2 \mathrm{~cm}$ tall $\times$ $7.6 \mathrm{~cm}$ i.d.) were packed with the same substrates, drained to $\mathrm{CC}$, frozen, and sawed into $2.5-\mathrm{cm}$ sections to determine water-holding capacity at each height. A finer substrate texture increased the amount of water throughout the container profile, but percent of total water for each strata remained similar. Container height and plant size (i.e., transplant or salable), in relation to substrate texture, should be considerations when producing containerized crops. In addition, bark texture alters water-holding capacity and water distribution within the container, ultimately affecting water management practices.
\end{abstract}

Soil texture is an intrinsic attribute defined as the distribution and proportion of particles at a given size to compose a given soil (Hillel, 1998). Knowledge of texture can be used to describe characteristics of soil relating to water-holding capacity, tortuosity, and infiltration rate. In soil, decreasing particle size results in smaller pores and an increased number of pores. Changes in pore size and number can affect water retention characteristics of soil and soilless substrates (Handreck and Black, 2002). A finer texture soil will retain greater amounts of water at higher tensions than a coarser texture soil or substrate because of smaller pores (Handreck and Black, 2002). Texture of soilless substrate has a similar impact on substrate physical properties as it has on soil physical properties. Texture for soilless substrates can

\footnotetext{
Received for publication 27 July 2007. Accepted for publication 8 Nov. 2007.

Research supported by funding appropriated to the North Willamette Research and Extension Center, Oregon State University, Aurora, OR.

We gratefully acknowledge Magdalena Zazirska for laboratory assistance.

${ }^{1}$ To whom reprint requests should be addressed; e-mail jim.owen@oregonstate.edu
}

be defined as the distribution and proportions of particle sizes in a substrate resulting from grinding, processing, and decomposition of the parent materials and added components. Mechanical analysis (Dane and Topp, 2002) of substrate particle size distribution is routinely performed to make inferences on infiltration, pore size and distribution, and, subsequently, water-holding capacity (Argo, 1998; Bilderback et al., 2005). Drzal et al. (1999) separated soilless substrates into three size or texture classes; course (greater than $2.0 \mathrm{~mm}$ ), medium ( 0.5 to $2.0 \mathrm{~mm}$ ), and fine (less than $0.5 \mathrm{~mm}$ ) as suggested by Puustjarvi and Robertson (1975).

Substrate texture directly influences the substrate matric potential; however, this force can result in increased water-holding capacity at a given container height by overcoming the gravitational potential of 0.1 $\mathrm{kPa} \cdot \mathrm{cm}^{-1}$ from the bottom of the container (Milks et al., 1989). A water gradient occurs from the top to the bottom of a substrate in a container as a result of opposing matric and gravitational potentials. Matric potential in a substrate is constant throughout the container (assuming particle size distribution is constant), whereas gravitation potential in a substrate decreases from the top to the bottom of a container. Changes in total water potential, as a result of the combined effect of matric and gravitation potentials, causes a gradient of increasing substrate moisture from the top to the bottom of a container. This substrate moisture gradient results in an inverse relationship between air space (AS) and container capacity (CC) where AS decreases and $\mathrm{CC}$ increases from the top to the bottom of a substrate in a container. Substrate texture alters this moisture gradient by affecting the number and distribution of capillary and noncapillary pores (Argo, 1998).

Bilderback and Fonteno (1987) predicted the moisture gradient in a $17-\mathrm{cm}$ tall container at $2-\mathrm{cm}$ intervals using simulation models based on moisture characteristic curves of a 3 bark: 1 sand (by vol.) substrate. The predicted gradient had a $37 \%(110 \mathrm{~mL})$ increase in substrate moisture content from the top $(32 \% \mathrm{CC})$ to bottom $(69 \% \mathrm{CC})$ of a trade 1-gal container. This predicted moisture gradient within a container could greatly affect water management practices for ornamental plant growth throughout the production process. Direct measurement of the moisture gradient would be ideal to more assuredly determine moisture conditions throughout the profile of a soilless substrate. Kritz and Khaled (1995) developed a direct method to measure AS in relation to pot depth with peat-based substrates that used a drained, frozen column of substrate separated using detachable cylindrical rings from a unique, engineered device.

Douglas fir bark (DFB) used in soilless substrates in the northwest United States is commonly categorized as fine or medium bark when passing thru a $0.9-\mathrm{cm}$ or $2.2-\mathrm{cm}$ sieve, respectively (Buamscha, 2006). The objectives of this study were to 1) quantitatively determine the effect of container height on the physical properties $\left(\mathrm{CC}, \mathrm{AS}, \mathrm{D}_{\mathrm{b}}\right)$ of fine and medium DFB, 2) determine the effect of DFB particle size distribution on physical properties, and 3) directly measure water distribution in DFB in a 2.7-L container (\#1 container).

\section{Materials and Methods}

Container height. Douglas fir (Pseudotsuga menziesii) bark samples of two different textures (screened to less than 0.9 or less than $2.2 \mathrm{~cm}$ ) were collected from larger piles intended for nursery container production (Marr Bros., Monmouth, OR). DFB samples were adjusted to $1.5 \mathrm{~g} \cdot \mathrm{g}^{-1}$ mass wetness, allowed time to equilibrate, and packed in aluminum cores $(3.8 \mathrm{~cm}, 7.6 \mathrm{~cm}$, or $15.2 \mathrm{~cm}$ tall $\times 7.6 \mathrm{~cm}$ i.d.) according to methods described by Fonteno and Bilderback (1993). There were three replications for each substrate texture. Aluminum cores were attached to North Carolina State University Porometers (Horticultural Substrates Laboratory, North Carolina State University, Raleigh, NC) for determination of AS. Cores were weighed, oven-dried for $4 \mathrm{~d}$ at $110{ }^{\circ} \mathrm{C}$, and weighed again to determine CC. Total porosity (TP) was calculated as the sum of AS and CC. All physical properties (TP, AS, CC) were 
calculated as the algebraic mean of the core. Bark bulk density $\left(D_{b}\right)$ was calculated as $\mathrm{g} \cdot \mathrm{cm}^{-3}$ on a dry basis.

Water distribution. Cores $(15.2 \mathrm{~cm}$ tall $\times$ $7.6 \mathrm{~cm}$ i.d.) were cut from schedule 40 polyvinyl chloride (PVC) rigid conduit. The same DFB described previously was similarly packed into PVC cores. There were six replications for each substrate texture. These cores were placed on acrylic discs $(10 \mathrm{~cm}$ diameter, $0.3 \mathrm{~cm}$ thick). Drain holes $(0.7 \mathrm{~cm}$ diameter) were drilled into the discs to match the same pattern and placement of those on the NCSU Porometer. Cores were slowly bottom saturated with water over a $15-\mathrm{min}$ period and then allowed to drain for $60 \mathrm{~min}$. Drained cores were placed in a freezer at $-21{ }^{\circ} \mathrm{C}$ for $7 \mathrm{~d}$. Frozen cores were cut into strata $(\approx 2.5 \mathrm{~cm}$ tall) with a Ridgid compound miter saw (Ridgid Tool, Elyria, $\mathrm{OH}$ ) equipped with a $0.2-\mathrm{cm}$ thick, $25-\mathrm{cm}$ diameter saw blade with 200 teeth (Oldham Co., Brooklyn, NY). Actual height of cut strata was approximated by measuring the height at four points along the circumference of each cut section; volume was calculated for each strata separately using its averaged height. Each cut strata was weighed, oven-dried at $60{ }^{\circ} \mathrm{C}$ for $3 \mathrm{~d}$, and weighed again to determine CC. Particle size distribution $(n=3)$ at each cut strata was determined by pooling two ovendried $\left(60{ }^{\circ} \mathrm{C}\right)$ samples from the same strata and passing them through $19,12.5,6.3,4.0$, $2.8,2.0,1.4,1.0,0.71,0.50,0.35,0.25,0.18$, and $0.106 \mathrm{~mm}$ soil sieves. Particles $0.106 \mathrm{~mm}$ or less were collected in a pan. Sieves and pans were shaken for 3 min with a RX-29 RoTap test sieve shaker (278 oscillations/min, $150 \mathrm{taps} / \mathrm{min}$ ) (W.S. Tyler, Mentor, OH). All cut strata within a medium or fine texture were pooled to determine particle size dis- tributions for fine (less than $0.9 \mathrm{~cm}$ ) or medium (less than $2.2 \mathrm{~cm}$ ) textured DFB.

Data analysis. Data were analyzed with multivariate analysis of variance using Wilk's lambda for the test statistic to determine the influence of main effects on composite substrate physical properties (CC, AS, $\mathrm{TP}$, and particle size distribution). Univariate analysis of variance was used to determine influence of main effects on individual substrate physical properties. Means separation with Tukey's test $(\alpha=0.05)$ and trend analysis with contrast statements were used compare physical properties response to container height. Statistical analysis was conducted on all data using SAS software (SAS version 9.1; SAS Institute, Cary, NC).

\section{Results and Discussion}

Core height. Hydraulic properties of the two bark textures were affected by the height of the core in which they were measured. With increasing core height, AS increased linearly and CC decreased linearly in both bark textures (Table 1). The total decrease in $\mathrm{CC}$ from the smallest to the tallest container was $14 \%\left(2.5 \% \mathrm{~cm}^{-1}\right.$; linear change in CC per $\mathrm{cm}$ height) for fine bark (less than $0.9 \mathrm{~cm}$ ) but only $8 \%\left(1.4 \% \mathrm{~cm}^{-1}\right)$ for medium bark (less than $2.2 \mathrm{~cm})$. Air space decreased linearly $1.6 \% \mathrm{~cm}^{-1}$ in the medium bark and $2.0 \% \mathrm{~cm}^{-1}$ in the fine bark in relation to core height. Total porosity increased linearly with increasing core height in the medium bark $\left(0.6 \% \mathrm{~cm}^{-1}\right)$, but decreased linearly $0.5 \%$ $\mathrm{cm}^{-1}$ in the fine bark (Table 1). This was unexpected because TP is thought not to change with container geometry (Milks et al., 1989). Tilt and Bilderback (1987) also reported inconsistent TP with increasing pro- portion of fine particles in pine bark and hardwood bark soilless substrates. A change in TP could be the result of an immeasurable redistribution of fines in substrate when preparing the substrate in the core (Ted Bilderback, NCSU Substrate Laboratory, personal communication) or increased compression from increasing substrate weight with rising column height. The linear decrease in the fine bark was a result of the $18 \%$ increase in the fine texture DFB bulk density $\left(D_{b}\right)$ with increasing container height (Table 1).

A consequence of these findings is how interpretation of physical property results performed by laboratories and growers might be affected by the height of the vessel used in measuring physical properties. There are two common approaches to measuring physical properties of container substrates. A method performed by commercial and academic laboratories uses the 7.6-cm tall NCSU Porometer used in this article and described by Fonteno and Bilderback (1993). Another technique, promoted as a farm-friendly approach, adapts the NCSU Porometer method for measurement in an actual container, commonly a 2.7-L (\#1) container that is typically $15.2 \mathrm{~cm}$ tall (Cooke et al., 2004). Yeager et al. (2006) offer the following general guidelines for container substrate physical properties regardless of method: AS should be $10 \%$ to $30 \%$; CC should be $45 \%$ to $65 \%$; and TP should be $50 \%$ to $85 \%$. Our data show a difference of $5 \%$ to $10 \%$ in $\mathrm{CC}$ results between 7.6- and 15.2-cm tall cores. Porometer results are relative comparisons of given substrates, but the actual $\mathrm{CC}$ and $\mathrm{AS}$ will change with experimental vessel or container height. Therefore, practitioners of laboratory or field physical properties analysis should be

Table 1. Physical properties of fine (less than $0.9 \mathrm{~cm}$ ) and medium (less than $2.2 \mathrm{~cm}$ ) Douglas Fir bark measured in aluminum core (7.6 cm diameter) of three different heights.

\begin{tabular}{|c|c|c|c|c|c|}
\hline Bark texture & Core ht $(\mathrm{cm})$ & Air $\operatorname{space}^{\mathrm{z}}(\%)$ & Container capacity $^{\mathrm{y}}(\%)$ & Total porosity $^{\mathrm{x}}(\%)$ & Bulk density $\left(\mathrm{g} \cdot \mathrm{cm}^{-3}\right)$ \\
\hline Normal ranges $^{\mathrm{w}}$ & & $10-30$ & $45-65$ & $50-85$ & $0.19-0.70$ \\
\hline \multirow{2}{*}{ Medium $(<2.2 \mathrm{~cm})$} & 7.6 & 38 & 43 & 81 & 0.19 \\
\hline & 15.2 & 44 & 38 & 82 & 0.19 \\
\hline \multirow[t]{3}{*}{ Fine $(<0.9 \mathrm{~cm})$} & 3.8 & 22 & 61 & 82 & 0.17 \\
\hline & 7.6 & 25 & 57 & 81 & 0.19 \\
\hline & 15.2 & 31 & 47 & 79 & 0.20 \\
\hline \multicolumn{6}{|c|}{ Univariate sources of variation } \\
\hline Bark texture $(\mathrm{T})$ & & $0.0001^{\mathrm{u}}$ & 0.0001 & 0.7638 & 0.7526 \\
\hline Container height $(\mathrm{H})$ & & 0.0001 & 0.0001 & 0.6219 & 0.0001 \\
\hline $\mathrm{T} \times \mathrm{H}$ & & 0.3683 & 0.2027 & 0.0037 & 0.0378 \\
\hline \multicolumn{6}{|c|}{ Multivariate sources of variation ${ }^{t}$} \\
\hline Bark texture $(\mathrm{T})$ & & 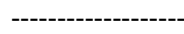 & - & ---------------------- & NA \\
\hline Container height $(\mathrm{H})$ & & ----------------- & ----------- $0.0001 \quad$------- & ------------------- & NA \\
\hline
\end{tabular}

${ }^{2}$ Total porosity - container capacity.

${ }^{\mathrm{y}}$ Predicted as percent volume at drainage.

xPercent volume at atmospheric pressure, $0.4 \mathrm{kPa}$

"Normal ranges cited by Southern Nurs. Assoc. Best Mgmt. Practices Guide for Producing Container-Grown Plants (Yeager et al., 2006).

${ }^{v}$ Linear $(\mathrm{L})$ or quadratic $(\mathrm{Q})$ response significant at $P \leq 0.05(*), P \leq 0.01(* *)$, or $P \leq 0.001(* * *)$, respectively.

"P values.

${ }^{\text {t}}$ Air space, container capacity, and solids were analyzed with multivariate analysis of variance.

$\mathrm{NA}=$ not applicable. 
aware that the height of the vessel they are using to perform the procedure will affect results and interpretation of a given substrate physical properties.

Adhering to given guidelines may change with container height. Bulk density was unaffected by container height with medium bark (mean $0.18 \mathrm{~g} \cdot \mathrm{cm}^{-3} \pm 0.005 \mathrm{SE}$ ) but increased linearly with container height with fine bark (Table 1). Increased $D_{b}$ and the measured decrease in TP of fine bark may have resulted from the packing procedure or additional weight of substrate with increasing height. Medium bark may have been more resistant to the effects of tamping while fine bark particles packed more closely together as the height of the container (and thus the weight of the total packing column) increased. This is a similar phenomenon as compaction in soil, in which $\mathrm{D}_{\mathrm{b}}$ increases in relation to compaction or pressure is related to soil texture (Hillel, 1998). A similar effect of fine particles on substrate $D_{b}$ was described by Tilt and Bilderback (1987) who reported an $31 \%$ increase in $\mathrm{D}_{\mathrm{b}}$ with a $27 \%$ increase in fine particles (less than $0.5 \mathrm{~mm}$ ) from pine bark and hardwood bark substrate.

Particle size distribution within a container. As expected, particle size distribution differed between the two bark textures (Table $2)$. Within each strata of the container, particle size distribution did not change $(P=$ $0.58)$ nor was there an interaction between bark texture and container strata $(P=0.43)$. Although numerical data indicated slight redistribution of fine particles to lower strata of the container, there was insufficient evidence to reject the null hypothesis of equal particle size distribution throughout the strata. The majority $(70 \%)$ of the medium bark particles occurred as coarse particles (greater than $2.0 \mathrm{~mm}$ ), whereas $63 \%$ of the fine bark particles were medium or fine particles (less than $2.0 \mathrm{~mm}$ ) (Table 2).

Puustjarvi and Robertson (1975) reported particle size could be used to estimate the number of capillary and noncapillary pores. Capillary and noncapillary pores occurring in substrates have particles sizes of 0.01 to $0.80 \mathrm{~mm}$ and 0.80 to $6.00 \mathrm{~mm}$, respectively (Puustjarvi and Robertson, 1975). Handreck and Black (2002) reported increasing the number of particles with a size of 0.10 to $0.25 \mathrm{~mm}$ increased the water-holding capacity of the substrate. Although researchers vary on the point of separation for fine and large particles, all have agreed that an increase in finer particles result in a larger number of small pores. Fine DFB had $12 \%$ of its particles in this 0.10 - to $0.25-\mathrm{mm}$ range compared with just $6 \%$ for medium DFB, which is likely the reason fine bark had greater CC. This increase in smaller pores could result in more uniform water distribution through lateral movement, decreased channeling, and subsequently reduced infiltration and tortuosity.

Water distribution within a container. Container capacity for the fine and medium bark in $15.2-\mathrm{cm}$ tall aluminum cores was $47 \%$ and $38 \%$, respectively (Table 1 ). These val- ues are just below or within the sufficiency range of $45 \%$ to $65 \%$ (Yeager et al., 2006). As predicted by Bilderback and Fonteno (1987), water content was not constant throughout the vertical profile of a container; however, the percent of total water for each strata remained similar regardless of bark size (Fig. 1). At 2.5-cm intervals from the top to the bottom of the substrate, $\mathrm{CC}$ increased from $31 \%$ to $57 \%$ in medium bark and $33 \%$ to $71 \%$ in fine bark. CC for the entire PVC column was $37 \%$ and $44 \%$ for the medium and fine bark, respectively. These values are close to the measured $\mathrm{CC}$ of the fine and medium bark in $15.2-\mathrm{cm}$ tall aluminum cores (Table 1). Particle size distribution and bulk density $\left(\right.$ mean $=0.20 \mathrm{~g} \cdot \mathrm{cm}^{-3} \pm 0.002$ $\mathrm{SE})$ (data not presented) did not change from the top to the bottom strata $(2.5-\mathrm{cm}$ tall sections) of the container; therefore, it can be assumed that TP was constant throughout the substrates. Using the TP calculated with the $15.2-\mathrm{cm}$ tall aluminum containers as an estimate of the TP in the $15.2-\mathrm{cm}$ tall PVC containers, AS can be estimated for each strata. Air space of medium and fine DFB exceeded $30 \%$ in the top 12.7 and $10.2 \mathrm{~cm}$ for medium and fine bark, respectively. Sufficiency ranges for CC and AS vary by source (Jarvis et al., 1996; Ownley et al., 1990). Most agree that AS should be from $10 \%$ to $30 \%$ (Yeager et al., 2006). Considering most propagation material planted into $2.7-\mathrm{L}(\# 1)$ containers (typically $15 \mathrm{~cm}$ tall) will have root systems that reach 2 to $4 \mathrm{~cm}$ deep, AS may be too high and water retention low in

Table 2. Particle size distribution and particle size range of fine (less than $0.9 \mathrm{~cm}$ ) and medium (less than $2.2 \mathrm{~cm})$ Douglas Fir bark (DFB) in a polyvinyl chloride core $(15.2 \mathrm{~cm}$ tall $\times 7.6 \mathrm{~cm}$ i.d.).

\begin{tabular}{|c|c|c|c|c|}
\hline \multirow[b]{2}{*}{ Particle size (mm) } & \multicolumn{2}{|c|}{ Particle size distribution } & \multicolumn{2}{|c|}{ Particle size range ${ }^{\mathrm{z}}$} \\
\hline & Fine DFB (\%) & $\begin{array}{l}\text { Medium } \\
\text { DFB (\%) }\end{array}$ & Fine DFB (\%) & $\begin{array}{l}\text { Medium } \\
\text { DFB (\%) }\end{array}$ \\
\hline$>6.30$ & 3 & 26 & \multicolumn{2}{|c|}{ Coarse particles } \\
\hline $6.30-4.00$ & 9 & 23 & & \\
\hline $4.00-2.80$ & 13 & 13 & \multirow[t]{2}{*}{37} & \multirow[t]{2}{*}{70} \\
\hline $2.80-2.00$ & 12 & 8 & & \\
\hline $2.00-1.40$ & 11 & 6 & \multicolumn{2}{|c|}{ Medium particles } \\
\hline $1.40-1.00$ & 9 & 5 & & \\
\hline $1.00-0.71$ & 8 & 4 & \multirow{2}{*}{38} & \multirow{2}{*}{18} \\
\hline $0.71-0.50$ & 9 & 4 & & \\
\hline $0.50-0.36$ & 7 & 3 & \multicolumn{2}{|c|}{ Fine particles } \\
\hline $0.36-0.25$ & 6 & 3 & & \\
\hline $0.25-0.18$ & 5 & 2 & \multirow[t]{3}{*}{25} & \multirow[t]{3}{*}{12} \\
\hline $0.18-0.106$ & 4 & 2 & & \\
\hline Less than 0.106 & 3 & 2 & & \\
\hline \multicolumn{5}{|l|}{ Source of variation } \\
\hline Bark texture $(\mathrm{T})$ & \multicolumn{2}{|c|}{ 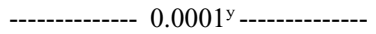 } & \multicolumn{2}{|c|}{0.0001} \\
\hline Container strata $^{\mathrm{w}}(\mathrm{S})$ & \multicolumn{2}{|c|}{ 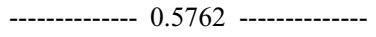 } & \multirow{2}{*}{\multicolumn{2}{|c|}{$\begin{array}{l}\mathrm{NA}^{\mathrm{x}} \\
\mathrm{NA}\end{array}$}} \\
\hline $\mathrm{T} \times \mathrm{S}$ & --------------- 0.4 & ------------ & & \\
\hline
\end{tabular}

${ }^{\mathrm{z}}$ Coarse: greater than $2.0 \mathrm{~mm}$; medium: 0.50 to $2.0 \mathrm{~mm}$; fine: less than $0.50 \mathrm{~mm}$.

${ }^{y} P$ values.

${ }^{\mathrm{x}}$ Not applicable for pooled data over container strata.

w2.5-cm tall sections from bottom to top of core.
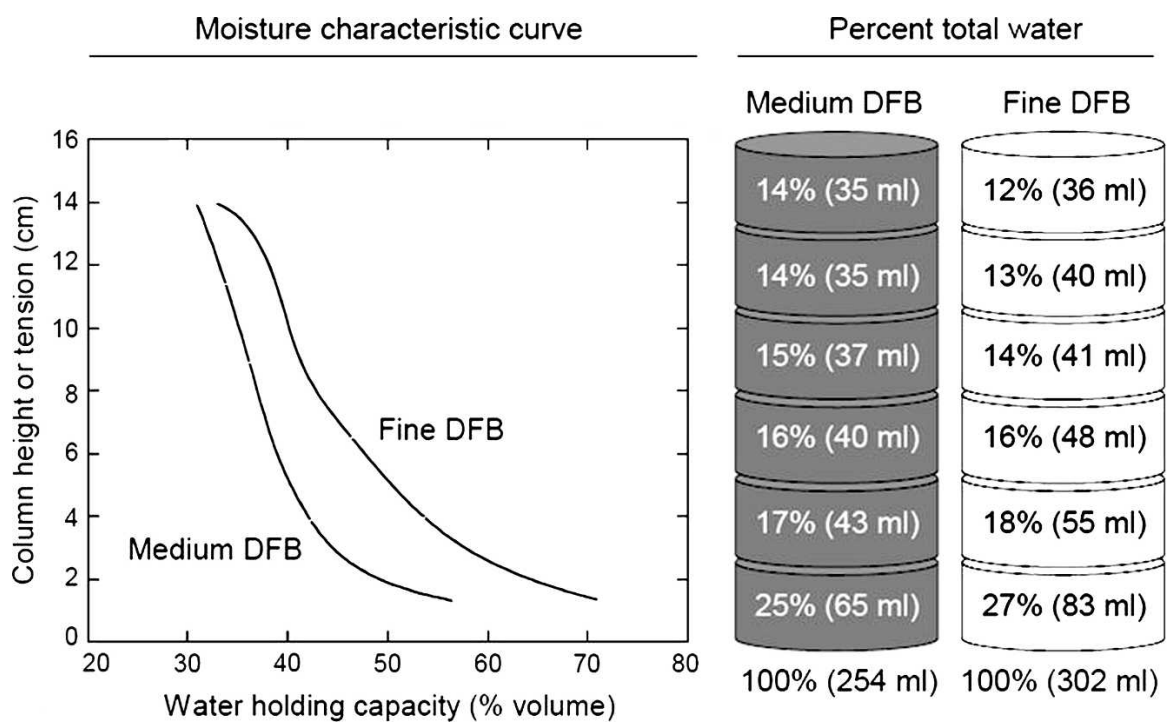

Fig. 1. Water distribution of fine $(<0.9 \mathrm{~cm})$ and medium $(>2.2 \mathrm{~cm})$ douglas fir bark (DFB) in $15-\mathrm{cm}$ polyvinyl chloride cores illustrated as a moisture characteristic curve and percent of total water as a function of container height. 
the substrate accessible by these roots early in the production cycle. This can lead to difficultly in maintaining needed substrate moisture content for liners, transplants, or seedlings.

Other practical consequences of the moisture gradient within the container include biological properties of the substrate. Greater saturation of the substrate at the bottom of the container would likely buffer temperature more than the drier substrate at the surface of the container. Temperature gradients (alone or interacting with moisture gradients) could influence biological reactions such as nitrification or substrate decomposition. The greater moisture content or saturated conditions at the bottom of a container could increase disease potential and reduce metals, changing available nutrition and nutrient fate. Substrate chemical and physical properties studied in nursery containers thus far have primarily considered the composite substrate. Our data suggest these properties can and should be studied in horizontal strata from the container surface to the bottom. Techniques used in this article also offer a simple method for studying substrate properties throughout the container strata.

In summary, a moisture gradient within container substrates composed of DFB is a result of increasing $\mathrm{CC}$ and decreasing AS from the top to the bottom of a substrate in the container, as predicted by Bilderback and Fonteno (1987). As the particle size of DFB decreases, the change in $\mathrm{CC}$ between the substrate at the top of the container and the bottom is more pronounced. As a result of the moisture gradient that develops when DFB is used as a container substrate, taller containers will have higher total AS and lower CC compared with smaller containers. These differences should be considered when laboratory or field tests are conducted to measure and compare container physical properties.

\section{Literature Cited}

Argo, W.R. 1998. Root medium physical properties. HortTechnology 8:486-494.

Bilderback, T.E. and W.C. Fonteno. 1987. Effects of container geometry and media physical properties on air and water volumes in containers. J. Environ. Hort. 5:180-182.

Bilderback, T.E., S.L. Warren, J.S. Owen, Jr., and J.P. Albano. 2005. Healthy substrates need physicals too! HortTechnology 15:9-13.

Buamscha, M.G. 2006. Chemical and physical properties of Douglas Fir bark relevant for the production of container crops in Oregon. Oregon State Univ., Corvallis, OR, MS Thesis.

Cooke, A., T. Bilderback, and M. Lorscheider. 2004. Physical property measurements in container substrates: A field quantification study. Proc. Southern Nurs. Assn. Res. Conf. 49:102104.

Dane, J.H. and G.C. Topp. 2002. Methods of soil analysis: Part 4-Physical methods. Soil Sci. Soc. Amer. Book Ser., No. 5, Madison, WI.

Drzal, M.S., W.C. Fonteno, and D.K. Cassel. 1999. Pore fraction analysis: A new tool for substrate testing. Acta Hort. 481:43-54.

Fonteno, W.C. and T.E. Bilderback. 1993. Impact of hydrogel on physical properties of coarse- structured horticultural substrates. J. Amer. Soc. Hort. Sci. 118:217-222.

Handreck, K. and N. Black. 2002. Growing media for ornamental plants and turf. 3rd ed. Univ. New South Wales Press, Sydney.

Hillel, D. 1998. Environmental soil physics. Academic Press, San Diego, CA.

Jarvis, B., J.B. Calkins, and B.T. Swanson. 1996. Compost and rubber tire chips as peat substitutes in nursery substrate: Effects on chemical and physical substrate properties. J. Environ. Hort. 14:122-129.

Kritz, G. and T. Khaled. 1995. Method of measuring air space and moisture content at different pot depths. Acta Hort. 401:107-114.

Milks, R.R., W.C. Fonteno, and R.A. Larson. 1989. Hydrology of horticultural substrates: II. Predicting physical properties of media in containers. J. Amer. Soc. Hort. Sci. 114: $53-56$.

Ownley, B.H., D.M. Benson, and T.E. Bilderback. 1990. Physical properties of container substrate and relation to severity of Phytophthora root rot of rhododendron. J. Amer. Soc. Hort. Sci. 115:564-570.

Puustjarvi, V. and R.A. Robertson. 1975. Physical and chemical properties, p. 23-38. Robinson, D.W. and J.G.D. Lamb (eds.). Peat in horticulture. Academic Press, London.

Tilt, K.M. and T.E. Bilderback. 1987. Physical properties of propagation media and their effects on rooting of three woody ornamentals. HortScience 22:245-247.

Yeager, T., T. Bilderback, D. Fare, C. Gilliam, J. Lea-Cox, A. Niemiera, J. Ruter, K.M. Tilt, S.L. Warren, T. Whitwell, and R. Wright. 2006. Best management practices: Guide for producing nursery crops. 2nd ed. Southern Nurs. Assn., Atlanta. 